\title{
Hepatitis A Antibody Measurement
}

National Cancer Institute

\section{Source}

National Cancer Institute. Hepatitis A Antibody Measurement. NCI Thesaurus. Code C92534.

A quantitative measurement of the antibody reaction of a biological specimen to the Hepatitis A virus. 